\title{
MODAL SOSIAL DAN STRATEGI KEBERLANGSUNGAN HIDUP MASYARAKAT DAYAK NGAJU (Studi Kasus Pada Masyarakat Dayak Ngaju Desa Manusup di Kabupaten Kapuas Provinsi Kalimantan Tengah)
}

\author{
SOCIAL CAPITAL AND STRATEGIES FOR THE SURVIVAL OF DAYAK NGAJU PEOPLE \\ (Case Study in Dayak Ngaju Community of Manusup Village in Kapuas Regency of Central \\ Kalimantan Province)
}

\section{Bahrianoor}

Universitas Muhammadiyah Palangkaraya, Palangka Raya, Central Kalimantan, Indonesia

email:

bahrianoor16@yahoo.com

\section{Keywords: \\ Social Capital \\ Livelihood \\ Bonding \\ Bridging \\ Linking Capital}

\section{Kata Kunci:}

Modal Sosial

Mata pencaharian

Ikatan

Menjembatani

Menautkan Modal

Published

Oktober 2020

\begin{abstract}
Abstrak
Penelitian ini membahas peran modal sosial dalam memenuhi sumber penghidupan pada komunitas Adat Dayak Ngaju di Desa Manusup Kalimantan Tengah. Penelitian ini adalah penelitian kualitatif dengan desain deskriptif. Hasil penelitian ini menunjukkan bahwa modal sosial mempunyai peran penting dan berfungsi dalam memperluas hubungan kerjasama, baik hubungan dalam kebutuhan sosial maupun hubungan dalam kebutuhan sumber penghidupan.hubungan dalam kebutuhan sosial berfungsi melahirkan solidaritas sosial yang terbentuk melalui institusi sosial keadatan maupun agama. Sedangkan hubungan dalam kebutuhan sumber penghidupan berfungsi menopang ketahanan ekonomi dengan cara membuka interaksi dalam penguatan jaringan yang saling menguntungkan, baik yang bersifat bonding, bridging dan linking capital.
\end{abstract}

Bonding capital berperan membentuk kebersamaan dan kerekatan hubungan emosional dan mampu memperkuat pertalian internal. Bridging capital mampu membuka jalan dan menstimulasi perkembangan komunitas. Sedangkan, linking capital, membawa manfaat yang besar terhadap kemajuan desa Manusup, yaitu kemajuan dan pengembangan potensi keahlian yang dimiliki dalam mendapatkan sumber penghidupan.

\section{PENDAHULUAN}

Keberlangsungan hidup daerah pedesaan khususnya pada komunitas lokal pedalaman, dewasa ini cenderung mengalami perubahan yang signifikan. Adanya penguasaan hutan yang luas dan semakin terbukanya akses jalan, telah menyebabkan aktivitas kehidupan mereka mengalami berbagai macam perubahan. Selain itu, daya dukung lingkungan alam yang semakin menurun sebagai akibat dari penguasaan hutan dalam konversi lahan untuk proyek pembangunan, dapat menimbulkan kerentanan sosial bagi masyarakat lokal sekitar. (suara pembaruan agrarian, edisi ix/Desember 20।3-Februari 2014)

Dalam kontek perubahan, sifat lokalitas menjadi sebuah muatan penting dalam menentukan interaksi dalam menyikapi dinamika perubahan. Nilai-nilai lokal yang melekat pada struktur sosial komunitas adat dapat menghasilkan rasa solidaritas tinggi dalam jalinan hubungan kerjasama diantara mereka. Lebih dari itu, tantangan atas dinamika perubahan dapat menimbulkan 
kesadaran secara umum untuk melakukan berbagai respon, sikap dan tindakan mereka terhadap kepentingan ekonomi dalam kebertahanan untuk keberlangsungan hidup.

Saat ini di wilayah pedalaman Kalimantan Tengah, khususnya pada komunitas adat yang ada di Manusup Kabupaten Kapuas telah dilanda berbagai perubahan sosial akibat penguasaan hutan yang luas. Adanya praktik pembukaan lahan untuk perusahaan perkebunan sawit, program transmigrasi oleh pemerintah dan pembangunan infrastrukur jalan di pedesaan, adalah stimulan terjadinya perubahan. Akibatnya, Komunitas lokal adat Dayak Manusup akan merespon perubahan tersebut dengan berbagai tindakan sebagai strategi adaptasi agar tetap survive.

Terjalinnya hubungan sosial dengan kelompok lain atau bahkan dengan koorporasi seakan mempengaruhi masyaraka Ngaju dalam sebuah struktur sosial baru. Terjadinya perubahan sosial, kiranya membuat Masyarakat Dayak Ngaju telah menginterpretasi nilai-nilai baru yang diterapkan kepada mereka dan berupaya melakukan penyesuaian diri dengan tetap mempertahankan kelekatan sosial sebagai solidaritas bersama dalam rangka mempertahankan keberlangsungan hidup.

Berkaitan dengan hubungan sosial, dalam masyarakat Ngaju di Manusup telah tercermin adanya interaksi sosial yang melahirkan perilaku individu serta tindakan bersama yang masuk ke dalam berbagai hubungan yang dapat digunakan untuk mencapai tujuan. Misalnya membuka hubungan sosial bersama etnis lain dan pola hubungan kerja dengan pihak perusahaan atau hubungan kerja dengan komunitas diluar dilingkungan mereka. Dalam proses tersebut, tidak jarang juga terkandung tindakan yang bersifat adaptif dan inovatif yang juga menjadi bagian dari proses relasi sosial yang membentuk dinamika hubungan sosial antara masyarakat Adat dengan kehidupan disekitarnya.

Hubungan sosial yang dijalankan tersebut tentunya merupakan wujud dari modal sosial dan juga jaringan sosial yang merupakan aset yang sangat bernilai. Sebuah Jaringan tentu memberikan dasar bagi kohesi sosial untuk mendorong orang bekerja satu sama lain dan tidak sekedar dengan orang yang mereka kenal secara langsung untuk memperoleh timbal balik John Field, 2003). Maka dengan meletakkan modal sosial sebagai aset penting terhadap kehidupan, memungkinan komunitas Dayak Ngaju di Manusup untuk memperluas dan memperdekat akses mereka terhadap sumbersumber atau fasilitas yang menyediakan kebutuhan dasar.

Dengan menemukan modal sosial pada komunitas Dayak Ngaju di Manusup, nanti terlihat bagaimana kelemahan/kekuatan dari hubungan sosial yang terjalin di lingkungan mereka apakah bisa berperan sebagai kekuatan sosial yang dapat digunakan untuk mempertahankan hidupnya. Berperan atau tidaknya modal sosial dalam suatu komunitas sangat dipengaruhi oleh tindakan para aktor dalam suatu struktur sosial. Komunitas yang memiliki modal sosial tinggi akan cenderung lebih efesian dan efektif menjalankan berbagai kebijakan untuk mensejahterakan dan memajukan komunitasnya dan dapat memungkinkan menyelesaikam kompleksitas persoalan dengan lebih mudah. Komunitas yang bersatu dan memiliki hubungan keluar lingkungan kelompoknya (eksternailtas) secara intensif akan bisa menata kehidupan komunitasnya secara lebih baik. Berangkat dari gambaran diatas, penelitian ini nantinya akan lebih menfokuskan peran dari modal sosial yang terdapat dalam komunitas Dayak Ngaju di Manusup dalam mengerakkan kebersamaan sebagai daya dukung untuk mencapai tujuan kemajuan bersama. Oleh karena itu penting kiranya meletakkan modal sosial sebagai sumber daya untuk mendapatkan aset-aset penghidupan dan digunakan sebagai strategi yang bisa bermanfaat demi kebertahanan hidup untuk mendukung eksistensi mereka dalam menghadapai arus perubahan yang lebih luas.

Mencermati hal tersebut, kiranya memang perlu melihat secara kompherensif mengenai tradisi sosial 
yang berkembang dalam bentuk interaksi rutin masyarakat, sekaligus guna memunculkan modal sosial, yang mengarah kepada pengembangan bonding capital, bridging capital dan linking capital pada masyarakat Manusup. Modal sosial mungkin saja dapat diandalkan, sebagai kekuatan sosial yang dapat digunakan untuk menghadapi masalah-masalah yang ada dilingkungan mereka dalam upaya keberlangsungan hidup mereka.

\section{METODE PENELITIAN}

Penelitian ini menggunakan pendekatan kualitatif yang berupaya menghasilkan data deskripsi berupa kata-kata tertulis atau lisan dari orang-orang dan perilaku yang dapat diamati. Selain itu peneliti juga menggunakan Teknik pengumpulan dengan menggunakan wawancara mendalam, observasi dan studi dokumentasi. Wawancara mendalam digunakan untuk menggali tindakan kolektif dan mencatat berbagai aktivitas kehidupan mereka dalam menghadapi masalahmasalah dengan memunculkan modal sosial yang berkembang di lingkungan mereka. Teknik observasi digunakan untuk melihat situasi sosial dan hasi-hasil kerajinan masyarakat yang memanfaatkan jaringan dan kerjasama masyarakat. Studi dokumentasi dilakukan dengan telaah hasil-hasil pembangunan relasi desa yang berkaitan dengan eksistensi masyarakat Dayak ngaju.

\section{Proses dan Strategi Keberlangsungan Penghidupan (Livelihood)}

Dalam kerangka penghidupan berkelanjutan (Saragih, Lassa, Afan 2007:2) Secara etimologis, makna kata "Livelihood" itu meliputi aset atau modal (alam, manusia, financial, sosial dan fisik), aktivitas di mana akses atas aset dimaksud dimediasi oleh kelembagaan dan relasi sosial yang secara bersama mendikte hasil yang diperoleh oleh individu maupun keluarga. Kata "akses" didefenisikan sebagai "aturan dan norma sosial yang mengatur atau mempengaruhi kemampuan yang berbeda antara orang dalam memliki, mengontrol, mengklaim atau menggunakan sumber daya seperti penggunaan lahan di desa atau komunitas kampung”.
Pendekatan konsep penghidupan disini dapat diidentikkan dengan strategi mendapatkan nafkah. Seseorang bertujuan memperoleh kebutuhan ekonomi untuk meningkatkan efisiensi dan kesamaan perolehan manfaat pada masyarakat. Jadi Hal penting dalam konsep penghidupan adalah strategi mempertahankan kelangsungan hidup dengan cara memanfaatkan sumber penghidupan yang tersedia.

Secara konseptual Chambers dan Conway dalam Ellis (2000), menulis lima tipe modal yang dapat dimiliki atau dikuasai suatu komunitas untuk mencapai keberlangsungan hidupnya, yaitu modal manusia (human capital), modal fisik (Physical capital), modal financial (financial capital), modal alam (natural capital) dan modal sosial (social capital).

\section{Jejak Pemikiran dan Teori Modal Sosial.}

Menyususn sebuah konsep hubungan sosial sebagai suatu jaringan memungkinkan untuk mengidentifikasi struktur hubungan sosial serta isi di dalamnya. Jaringan sosial klasik dalam sosiologi, berkaitan dengan aspek jaringan yang penting guna memahami modal sosial dan membentuk sebuah pemahaman yang kaya bagi studi tentang jaringan sosial dalam penelitian modal sosial.

Konsep modal sosial pada awalnya telah berkembang pada tahun 1916 dengan adanya tulisan Hanifan yang menekankan pentingnya partisipasi masyarakat dalam peningkaan kinerja disekolah. sebagaimana yang dikutip Woolcock dan Narayun (1999:5), Hanifan menjelaskan hubungan positif dan partisipasi tersebut dengan memasukkan konsep modal sosial yang digambarkan sebagai berikut:

\footnotetext{
"Sesuatu yang nyata pada hakekatnta sangat berharga dalam kehdiupan sehari-hari orangorang, yaitu perbuatan yang baik, persahatan simpati dan hubungan sosial di antara individuindividu dan keluarga-keluarga yang merupakan suatu unit sosial. jika (seorang individu) melakukan kontak dengan tetanga mereka dan tetanga-tetangga mereka yang lain, disana akan terjadi akumulasi modal sosial, yang mungkin dapat segera memenuhi kebutuhan-kebutuhan sosialnya dan mungkin menghasilkan suatu potensi sosial yang cukup untuk meningkatkan
} 
kondisi kehidupan komunitasnya secara keseluruhan".

Dari penjelasan tersebut terlihat, hubungan yang terjalin antara seorang individu dengan para tetangganya dan tetangganya yang lain dalam suatu komunitas tertentu akan menghasilkan modal sosial yang dapat memenuhi kebutuhan-kebutuhan sosial mereka secara potensial dapat meningkatkan kehidupan masyarakatnya.

Meskipun gagasan mengenai berartinya ikatanikatan masyarakat tersebut muncul sekitar tahun 1950an, konsep tentang modal sosial kemudian diperkenalkan kembali oleh Bourdieu (1986) dan kemudian mendapatkan kerangka teoritik yang jelas oleh Coleman (1988, 1990)'. sebagai orang pertama yang mengembangkan konsep pokok dan membuka jalan operasionalisasi bagi tujuan penelitian empiris. Putnam (1993, 1995, 2000) behasil memindahkan konsep modal sosial ini ke dalam pembahasan yang lebih luas.

Putnam, berdasarkan hasil penelitiannya di wilayah pedesaan berkesimpulan bahwa suatu jaringan yang giat dilakukan oleh perkumpulan di tingkat grassroot dapat menjadi sesuatu yang esensial bagi pertumbuhan, terutama ketika investasi fisik, teknologi yang diperlukan menjadi mahal. Dengan demikian, modal sosial dipandang sebagai komponen vital dalam pembangunan ekonomi. berdasarkan hasil penelitian tersebut, sebagaimana (Putam 1993, dalam Field) berpendapat:

"Bagian-bagian dari organisasi sosial seperti rasa saling percaya, norma, dan jaringan, yang dapat meningkatkan efisiensi masyarakat dengan memfasilitasi tindakan-tindakan yang terkoordinasi” (Putnam, 1993:I67)

Menurut Putnam, kepercayaan, norma dan

jaringan yang terdapat dalam suatu komunitas dianggap

1 Coleman mengartikan modal sosial, tdak secara harfiah, melainkan berdasarkan fungsinya. fungsi tersebut diidentifikan berdaarkan konsep "modal sosial" sebagai sebuah nilai dari aspek struktur sosial yang bagi aktor dapat dipergunakan sebagaia sumber dari apa yang dapat mereka gunakan untuk mencapai keinginan sebagai investasi modal sosial yang dapat memberikan kekuatan diri pada anggotanya dan seara kumulatif dapat menjadi suatu aset sosial yang dapat menfasilitasi kerjama di masa depan.

Gagasan inti dari teori modal sosial Putnam adalah bahwa jaringan sosial memiliki nilai, kontak sosial memengaruhi produktivitas individu dan kelompoknya. istilah itu sendiri menurut Putnam didefenisikannya merujuk pada hubungan antar inividu, jaringan sosial dan norma resiprositas dan keterpercayaan yang tumbuh dari hubungan-hubungan tersebut.

Selain defenisi modal sosial, hal yang menarik untuk diamati dalam suatu kasus adalah mengenai tipe modal sosial. Michael Woolcock membuat pemisahan tentang tipe modal sosial sebagai berikut:

- Bonding: modal sosial yang mengikat, yang berarti ikatan antar orang dalam situasi yang sama, seperti keluarga dekat, teman akrab dan rukun tetangga

- Bridging: modal sosial yang menjembatani, yang mencakup ikatan yang lebih longgar dari beberapa orang, seperti teman jauh dan rekan sekerja

- Linking: modal sisal yang menghubungkan, yang menjangkau orang-orang yang berada pada situasi berbeda, seperti mereka yang sepenuhnya ada diluar komunitas, sehingga mendorong anggotanya memanfaatkan banyak sumber daya daripada yang tersedia di dalam komunitas.

(Woolcock, 200I:I3-14, dalam Field).

Menurut Woolcock (200I), orang miskin yang memiliki keterbatasan penghasilan, pendidikan, aset material, tidak ada asuransi maupun pinjaman kredit, mencoba bertahan dengan mengambangkan hubungan sosial mereka (baik bodning, bridging dan linking). Modal sosial tersebut menjadi sumber daya yang paling penting

mereka. aspek dari struktur sosial yang dikemukakan oleh Coleman (1988) mengarah pada keterlibatan kewajiban dan harapan, saluran informasi, normanorma dan sanksi efektif yang sesuai dan atau mendukung sikap tertentu dan ada dalam hubungan antar manusia. 
dan menjadi strategi utama dalam menghadapi tantangan hidup dan kesempatan. .

\section{HASIL PENELITIAN DAN PEMBAHASAN}

Menguatnya peran modal sosial melalui Rasa saling percaya, norma dan jaringan tentu memiliki nilai penting dalam berkembangnya hubungan sosial yang mereka jalankan. Hubungan yang dijalankan dapat diartikan suatu bentuk kerjasama untuk memecahkan berbagai permasalahan yang dihadapi secara bersama-sama. Dengan berkembangnya hubungan sosial tersebut, maka secara otomatis akan memberikan lebih banyak keuntungan atau manfaat yang dirasakan oleh masyarakat Manusup, khususnya dalam meningkatkan kehidupan sosial ekonomi mereka.

Kepercayaan, norma dan jejaring yang terdapat di dalam suatu masyarakat Manusup merupakan dasar bagi berkembangnya hubungan sosial yang lebih produktif dan memberikan lebih banyak keuntungan atau manfaat kepada warganya. Berikut ini merupakan hasil temuan adanya kepercayaan, norma dan Jejaring yang berkembang di antara masyarakat Manusup, maupun di luarlingkungan mereka.

\section{Peran Trust Terhadap Penghidupan}

Rasa saling percaya (trust) pada dasarnya merupakan perekar bagi berkembangnya suatu hubungan sosial. Melalui rasa kepercayaan tersebut, seseorang mempunyai harapan-harapan tertentu terhadap orang-orang yang dipercayainya. Dalam kehidupan bermasyarakat, komunitas Dayak Ngaju yang ada di Manusup, kepercayaan tumbuh dan berkembang dalam pola hubungan antar warga bersifat kekeluargaan, hubungan kekerabatan dan hubungan yang menekankan kepercayaan terhadap institusi yang dilakukan seharihari secara intensif. Mereka percaya bahwa dalam pergaulan hidup setiap hari di antara mereka tidak akan saling merugikan. Rasa saling percaya di antara anggota masyarakat tersebut dengan sendirinya telah menciptakan rasa aman dan tenteran bagi kehidupan warganya.

\section{Dimensi Trust pada Lembaga Adat}

Dimensi trust pada komunitas Dayak Ngaju Manusup dapat dilihat ketika mereka mengatasi masalah-masalah konflik antar warga. Untuk memelihara ketentraman antar warga, masyarakat Manusup tidak hanya memeliharnya melalui pola hubungan antar tetangga yang saling mempercayai, tetapi juga dipelihara melalui kelembagaan adat yang ada. Secara struktural, dalam pelaksanaan kepemerintahaan adat pada tingkat desa, seorang Mantir Adat merupakan pimpinan adat yang mempunyai peran cukup penting dalam memelihara ketentraan warga. Masyarakat percaya bahwa dewan adat tersebut cukup efektif dalam menyelesaikan permasalahan-permasalahan yang dihadapi. Dimensi Trust pada

\section{Dimensi Trus pada Relasi Bisnis}

Modal kepercayaan adalah salah satu modal yang sangat penting untuk dapat membantu perekonomian. Hubungan antara penjual dan pembeli akan sangat ditentukan dari seberapa besar kepercayaan yang dibangun. Dengan demikian, rasa percaya yang tumbuh tidak hanya I arah yaitu dari penguasaha kapal kepada penjual, tetapi juga sebaliknya kepercayaan bisa tumbuh dari pembeli kepada pengusaha kapal (penjual).

Dalam hal ini Tri Admojo menuturkan:

“Karna pelanggan kami sudah cukup banyak, jadi segala proses pemesanan kapal sangat mudah, biasanya para pembeli cukup menghubungi via telp saja seberapa banyak perahu yang ingin dipesan. Terkadang pembayaran dilakukan setelah segala proses pembuatan kapal selesai” (08 Agustus 2020)

Berdasarkan ungkapan di atas, ternyata rasa saling percaya tidak hanya tumbuh dalam hubungan sosial di antara masyarakat Dayak Ngaju yang ada di Manusup, tetapi juga ditanamkan dalam hal pengelolaan usaha. Keadaan seperti ini tentunya akan sangat membantu aktivitas pengembangan perekonomian mereka, upaya untuk mempertahankan hidup atau strategi adaptasi yang dilakukan akan mudah di dapat dengan modal sosial yang dimiliki, yaitu dengan membangun rasa saling percaya kepada para pelanggan 
sehingga membentuk suatu ikatan yang saling menguntungkan.

\section{Norma Sosial Komunitas Manusup}

Norma sosial akan sangat berperan dalam mengontrol bentuk perilaku yang tumbuh dalam masyarakat Manusup. Sebagaimana dari pengertian norma itu sendiri bahwa norma merupakan sekumpulan aturan yang diharapkan dipatuhi dan diikuti oleh anggota masyarakat pada suatu entitas sosial tertentu. Norma yang dimaksud di sini merupakan aturan-aturan baik secara tertulis maupun tidak yang berlaku di dalam komunitas Adat Dayak Ngaju di Manusup. Sejauh ini, norma-norma yang terdapat di lingkungan mereka lebih mengarah pada adanya komitmen yang harus dipatuhi bersama. Besarnya keinginan untuk tetap mempertahankan hidup di lingkungan tersebut, menjadi salah satu pendorong mereka berupaya menata kehidupan komunitasnya menjadi lebih baik, khususnya dalam hal keamanan, ketertiban dan kelestarian adat yang ada di lingkungan mereka.

\section{Partisipasi Dalam Suatu Jaringan}

Memahami jaringan sosial di komunitas Dayak Ngaju di Manusup, untuk mengakses sumberdaya dan kerjasama dalam mencapai tujuan bersama adalah bagian penting dari konsep modal sosial. Maka dalam deskripsi diabawah ini akan menggambarkan bagaimana partisipasi jaringan yang mereka bangun dalam upaya membawa kemajuan.

Jaringan dimaksud di sini adalah mengacu pada berbagai hubungan (relasi) atau suatu tempat perkumpulan yang dapat dijadikan sebaga sarana untuk menyampaikan berbagai informasi dan permasalahan yang terjadi untuk bersama-sama mencari jalan pemecahannya. Hubungan (relasi) tentu sangat berguna untuk memperkuat dan membentuk hubungan antar personal, individu dengan kelompok/institusi, serta jaringan antar institusi yang berkembang di lingkungan mereka, seperti dengan berlangsung dalam hubungan kerja yang bersifat ekonomi atau hubungan dalam dimensi lain, seperti hubungan psikologis dan budaya.
Berbagai factor yang melandasai hubungan diantara mereka atau terbentuknya sebuah jaringan tidak lepas dari berbagai informasi yang disampaikan melalui berbagai pertemuan. Misalkan, Selama ini bahwa kegiatan rapat atau musyawarah keadatan masyarakat Dayak Ngaju di Manusup masih menjadi suatu wadah yang paling efektif untuk menyampaikan berbagai informasi maupun membicarkan berbagai permasalahan yang perlu dipecahkan bersama-sama. Sering kali rapat dijadikan sebagai sarana musyawarah dalam menyelesaikan berbagai persoalan-persoalan yang terjadi.

Berbagai rapat dilakukan untuk menentukan beberapa hal penting untuk kemajuan desa, termasuk informasi-informasi penting yang harus disalurkan kepada masyarakat Manusup, misalkan berkaitan dengan masalah lingkungan, acara keadatan, pembangunan fasilitas sosial, pekerjaan dan informasi penting dari pemerintah daerah. Sebagai contoh dalam menyelenggarakan acara keadatan mereka biasanya melakukan musyawarah untuk menyiapkan semua perlengkapannya, termasuk membicarakan masalah pendanaan, sebagaimana yang diungkapkan oleh Jumadi:

"Sebelum melaksanakan berbagai acara di desa, apalagi berkaitan dengan upacara keadatan. Biasanya, kita mempersiapakan terlebih dahulu, baik masalah sarana dan prasanan yang akan di fungsikan. Selebihnya anggaran dana. Ini penting dibicakan agar kampung kami saling gotong royong” ( 4 Juni 2020).

Terbentuknya hubungan yang baik melalui pertemuan akan menjadikan masyarakat dalam ikatan yang kuat. Dengan tersedia ruang pertemuan tersebut, memudahkan mereka untuk membentuk jaringan dan saluran informasi yang efektif, seperti misalnya membentuk kepanitian acara keagamaan, perkawinan, kerja bakti atau pekerjaan yang melibatkan masyarakat. Bagi masyarakat yang terlibat secara langsung mungkin akan sangat mudah mendapatkan akses informasi, sehingga dengan mudah baginya untuk mengaktualisasikan jaringan sosial menjadi modal sosial.

Hubungan sosial dengan adanya pertemuan ternyata tidak hanya berkembang di dalam masyarakat 
Adat Dayak Ngaju saja. Tetapi, pertemuan juga melandasi hubungan sosial yang terjalin antara masywarakat Manusup dengan Penduduk Transmigrasi (orang Jawa). Selama ini, meskipun tidak dalam bentuk yang baku, antara masyarakat Manusup dan penduduk transmigrasi sering melakukan pertemuan informal untuk membicarkan hal-hal tertentu, seperti kerja bakti, persiapan pemilu dan lain-lain.

\section{Dinamika Bonding Social Capital, Bridging Social Capital dan Linking Social Capital}

Konsep Bonding social capital, Bridging social Capital dan Linking social capital merupakan salah satu konsep yang penting untuk digunakan dalam menjelaskan realitas dinamika masyarakat. Asumsi tersebut mengindikasikan bahwa modal sosial bukanlah realitas yang statis tetapi juga bersifat dinamis.

Sejak awal dinyatakan bahwa bonding social capital mengacu pada relasi-relasi di antara kelompokkelompok yang relative homogen. Dan bridging social capital merupakan terjadinya relasi-relasi antar kelompok yang heterogen, dan memperkuat ikatanikatan lintas kelompok tersebut. Sedangkan, linking social capital mengacu kepada relasi yang menghubungkan, yang menjangkau orang-orang yang berada pada situasi berbeda, seperti mereka yang sepenuhnya ada diluar komunitas, sehingga mendorong anggotanya memanfaatkan banyak sumber daya daripada yang tersedia di dalam komunitas.

\section{Modal Sosial Terikat (bonding capital)}

Homogenitas masyarakat Manusup pada mulanya terbentuk melalui pola pemukiman suku dayak yang berada dipinggir sungai mengikuti alur sungai. Seperti diketahui, bahwa dengan pola pemukiman tersebut akan membentuk suatu pola interaksi dengan tinggal berdekatan bersama kerabat dan masih memiliki tradisi yang sama untuk dilestarikan. Pola interaksi social tersebut telah digambarkan oleh hubungan yang berkelanjutan dalam suatu lingkungan diantara mereka.
Hubungan tersebut tercermin antara lain dari adanya berbagai kegiatan keadatan, sosial maupun keagamaan yang dilakukan secara bersama di lingkungan mereka. Seperti melalui kegiatan memapas lewu (salah satu contoh kegiatan keadatan), masyarakat Manusup berupaya untuk saling menghormati dan menunjung tinggi kebersamaan untuk kepentingan masyarakat desa. Selain itu, terdapatnya perkumpulan Fardhu kifayah juga sangat membantu sesama mereka untuk mengurangi beban dari keluarga yang ditinggalkan, misalnya pemenuhan biaya pemakanan. Maka dengan adanya keinginan untuk berkumpul dan saling mengumpulkan uang di antara para anggota tersebut, menunjukkan bahwa mereka membutuhkan adanya suasana kebersamaan yang dapat mendukung eksistensi mereka.

Menurut Putnam modal sosial terikat (bonding social capital) seperti telah dijelaskan diatas cenderung bersifat eksklusif dan sifatnya terbatas. Apa yang menjadi karakteristik dasar yang melekat, sekaligus sebagai cirri khasnya, yaitu baik kelompok maupun anggota kelompok, dalam konteks ide, relasi dan perhatian, lebih berorientasi ke dalam (inward looking). Perhatian fokusnya ada pada upaya menjaga nilai-nilai yang turun menurun telah diakui dan dijalankan sebagai bagian dari tata perilaku dan perilaku moral. Dapat dikatakan modal sosial seperti ini cenderung bersifat statis. Terlihat, bagaimana mereka masih mempertahankan sebagian norma, nilai-nilai kultural yang diwariskan oleh leluhurnya sebagai pedoman berperilaku.

Bagaimana pun juga bekerjanya bonding capital disini telah mampu menciptakan kekuatan dan kebaikan dalam hal menjalin kerjasama antar anggota komunitas mereka. Terbentuknya solidaritas sosial sangat membantu mereka dalam melakukan aktivitas dalam hidup bermasyarakat. Selain itu, memperkuat relasirelasi sosial antar warga untuk memenuhi tujuan-tujuan kolektif mereka, misalkan berbagi informasi dan ide untuk keberlangsungan hidup. Dengan demikian, maka kelembagaan solidaritas sosial yang terdapat di Manusup 
bisa menjadi investasi modal sosial yang dapat mengikat satu sama dalam nilai-nilai kebersamaan

Dalam bridging capital masyarakat Manusup telah terwujud dari relasi-relasi pada sebuah hubungan sosial yang tercermin dalam hubungan antara masyarakat manusup dengan masyarakat transmigrasi. Hubungan sosial tersebut terlihat dari berbagai kegiatan sosial maupun ekonomi seperti kegiatan keagamaan, aktivtas pasar dan kegiatan yang berkaitan dengan pekerjaan. Bagi masyarakat Manusup, berbagai bentuk kerjasama yang dijalankan tersebut ternyata mempunyai hubungan timbal balik (resiprkal) yang saling mengisi. Selama ini masyarakat Transmigrasi cukup banyak memberikan kontribusi dalam pembangunan desa, seperti pembuatan jembatan, memperbaiki jalan dan mampu bekerjasama dalam berbagai kegiatan sosial lainnya. Dengan demikian, kegiatan timbal balik yang saling menguntungkan tersebut akan memberikan harapan satu sama lain. Dengan adanya harapan yang bersifat tmbal balik tersebut, kedua belah pihak akan selalu berusaha mempertahankan ikatan sosial yang dijalin selama ini.

Pada prinsipnya bridging capital memiliki sikap dan pandangan yang terbuka dan senantiasa mengikuti perkembangan dunia di luar kelompoknya. Sebagaimana membangun kerjasama dengan kelompok lain, melakukan prinsip pengorganisasian yang berdasarkan kemajemukan dan terbuka terhadap ide dan masukan dari luar. Apa yang dimiliki oleh masyarakat Manusup mencerminkan sikap terbukanya terhadap penduduk diluar kelompok mereka.

Bekerjanya bridging disini mampu membuka jalan untuk lebih cepat berkembang di bandingkan desa lain, mereka memiliki pandangan yang bisa membawa untuk meningkatkan kualitas hidupnya. Dalam menghadapi pada situasi komplek sekarang, bisa dikatakan mereka mampu memngorganisir dirinya dengan menjaga pola hubungan kerjasama yang baik demi mewujudkan kesejahteraan bagi mereka, karna pada dasarnya bridging capital yang mereka miliki dapat menciptakan jaringan keluar yang kuat dan mampu beradaptasi.

\section{Linking Capital}

Setiap anggota Komunitas Dayak Ngaju di Manusup memiliki akses yang sama untuk membuat jaringan atau koneksi keluar kelompoknya dengan kekebasan yang dimiliki. Linking Capital tidak hanya merefleksikan kemampuan suatu perkumpulannya saja melainkan juga suatu individu atau kelompok secara luas. Menurut Michael Woolcock, linking capital bertugas menghubungkan. Pada konteks masyarakat Manusup, linking capital juga berfungsi untuk menghubungkan, menjangkau orang-orang yang berada pada situasi berbeda, seperti orang di luar komunitas mereka, dan mampu mendorong setiap anggota masyarakat memanfaatkan banyak sumber daya daripada yang tersedia di dalam komunitas.

Berlangsungnya linking capital sangat berguna bagi perkembangan masyarakat Manusup dalam mengembangkan kemajuan potensi serta meningkatkan pendapatan ekonomi. Salah satu cara dengan menjalin koneksi dan jaringan kerja dengan berbagai pihak diluar. Pola interaksi dan jaringan yang ia bentuk merupakan suatu peluang membuka jalan untuk memperkaya hubungan mereka dengan kelompok atau individu diluar mereka.

Dengan sikap dan relasi yang kuat tersebut menciptkan jaringan yang bisa menghubungkan mereka untuk kerjasama dengan pihak luat. Mereka yang terlibat dalam berbagai kelompok usaha dan individu memungkinkan mendapat keuntungan dari sebuah relasi yang dihubungkan. Kelompok pengrajin perahu misalnya mampu mengembangkan usahanya karena memiliki pelanggan khusus dari luar daerah, pengrajin kayu juga memperoleh keuntungan secara ekonomi karena mampu mengembangkan usaha tersebut ke luar daerah mereka, begitu juga petani karet bisa menjual hasil karetnya dengan mudah. Semua relasi tersebut tidak lepas dari networking yang mampu bekerja untuk 
menghidupkan segala sumberdaya yang di miliki mereka.

Dapat dkatakan, bentuk modal sosial yang menghubungkan ini telah mampu memberikan kontribusi besar bagi perkembangan kemajuan dan kekuatan masyarakat disekelilingnya.

Kemajuan lain dalam peran linking capital yang berfungsi dalam membawa kemajuan mereka adalah jalinan relasi yang baik kepada para pejabat dan Bupati setempat. Kedekatan tersebut memiliki manfaat yang besar bagi anggota masyarakat lain. Sebagai penghubung yang mampu menyalurkan berbagai pendapat serta ide pada seorang bupati, sangat membantu dalam kemajuan perkembangan desa mereka. Kemajuan tersebut dapat dicapai karena sebuah akses dalam kemampuan tokoh masyarakat tersebut dalam membangun relasi yang kuat. Misalkan mendapat bantuan terhadap pembangunan sarana pendidikan yang disalurkan untuk kepentingan masyarakat Manusup. Bantuan tidak hanya bersifat kebijakan, namun terkadang bantuan secara personal yang diberikan oleh bupati dalam menunjang sarana pendidikan madrasah yang ada di Manusup. Apa yang dimiliki oleh tokoh masyarakat tersebut, merupakan hubungan yang menghadirkan dampak positif terhadap masyarakat Manusup, melalui berbagai variasi hubungan yang dibangun berdasarkan kepentingan kelompok mereka. Namun unsure lain yang memegang peran penting adalah kemauan masyarakat itu sendiri untuk secara terus menerus proaktif baik dalam mempertahankan nilai, membentuk jaringan kerjasama maupun dengen menciptakan kerasi dan ide-ide baru dalam hal keberlangsungan hidupnya.

\section{KESIMPULAN}

Secara lebih rinci, kesimpulan-kesimpulan yang diperoleh dari penelitian ini adalah sebagai berikut:

Pertama, komunitas Dayak Ngaju yang tinggal di Manusup sebagian besar ditopang oleh ekonomi subsisten. Mereka melakukan penyesuaian-penyesuaian agar dapat bertahan hidup. Diantara penyesuaianpenyesuaian adalah dengan melakukan ketahan ekonomi melalui berbagai pemanfaatan sumberdaya yang tersedia. Mereka masih menekankan akses sumberdaya alam sebagai ketahanan hidup dengan memanfaatkan lahan yang tersisa.

Kedua, keberlangsungan hidup selain ditopang dengan ketahanan ekonomi subsisten, juga didukung oleh kentalnya hubungan kekerabatan. Hubungan kekerabatan ini didasari dengan saling membantu dan saling memberi. Mereka terbiasa hidup dengan bergotong royong serta bekerjasama dengan menciptakan hubungan timbale balik yang bisa saling menguntungkan, dan dibangun di atas rasa saling percaya yang ditopang oleh norma dan nilai sosial yang kuat.

Ketiga, Peran trust atau rasa percaya (mempercayai) masyarakat Manusup telah memberikan kontribusi pada peningkatan modal sosial. Trust yang melekat pada struktur sosial masyarakat Manusup telah dimanfaatkan untuk tujuan-tujuan kolektif. Tujuantujuan kolektif tersebut tidak hanya untuk kepentingan integritas dan stabilitas sosial masyarakat, melainkan juga untuk kepentingan kesejahteraan warga.

Keempat, tipologi modal sosial berupa bonding, bridging dan linking capital merupakan interaksi yang sangat penting bagi mereka dalam mendorong pertalian antar warga dan penguatan jaringan. Bonding capital bekerja untuk membentuk kebersamaan dan kerekatan hubungan emosional dan mampu memperkuat pertalian diantara sesama mereka. bridging capital bekerja membuka jalan dan menstimulasi perkembangan komunitas mereka. Dengan memiliki sikap dan pandangan terbuka sehingga dapat menggerakkan identitas yang lebih luas dan akomodatif untuk menerima perubahan. Mereka mampu menjalin koneksi dan jaringan kerja yang saling menguntungkan dengan kelompok diluar kelompoknya, dan juga mampu mewujudkan suatu kemajuan dalam pengembangan potensi yang mereka miliki. Dengan menjembatani keterbatasan bonding capital dan bridging capital, maka linking capital bisa berfungsi untuk menghubungkan atau menjangkau relasi dalam membentuk kerjasama dengan 
orang-orang diluar komunitas mereka, seperti dengan pejabat daerah, perusahan sawit, pelaku bisnis dan jalinan hubungan dengan para pelanggan pembeli perahu. Bekerjanya linking capital ternyata mampu membawa manfaat yang besar terhadap kemajuan desa , salah satunya adalah kemajuan sarana pendidikan dan pengembangan potensi keahlian yang dimiliki untuk meningkarkan pendapatan ekonomi mereka.

\section{REFERENSI}

Andi Muttaqien, Nurhanudin Ahmad, Wahyu Wagiman. 2012. Undang-undang perkebunan, Wajah Baru Agrarische Wet. Dasar dan alasan pembatalan Pasal-pasal Kriminalisasi oleh Mahkamah Konstitusi. Oleh lembaga, Elsam-Sawit WatchPilnet.

Badan Pusat Statistik Kabupaten Kapuas tahun. 2010. Kapuas dalam angka.

Bourdieu, Pierre. 2012. The Fiel of Cultural Production: Essays on Art and Literature, Terjemahan (Yudi Santosa). Kreasi Wacana, Bantul.

Bungin, Burhan. 20I0. Penelitian Kualitatif, Komunikasi, ekonomi, kebijakan publik, dan IImu Sosial lainnya.jakarta: kencana.

Carswell. Rahmat M. 2002. livelihood diversifikasi peningkatan pentingnya atau semakin diakui? Bukti dari Southem Ethiopia. Journal of internasional Development, I4 (6).

Chambers, R and Conway, G. R. 1992. Sustainable Rural Livelihood: konsep praktis untuk abab 2I. IDS DP296 Feb 1992, Brighton.

Ellis, F. 2000. Rural Livelihood and Diversity in Developing Countries. Oxford University Press.Oxford.

Field, John. 20I0. Social Capital. Diterjemahkan oleh Nurhadi, judul : Modal Sosial. Kreasi Wacana.

Fukuyama, Francis. 2005. The Great Disruption : Human Nature and the Reconstitution of Social Order. Diterjemahkan ke dalam bahasa Indonesia oleh Masri Maris, dengan judul : Guncangan Besar (Kodrat Manusia dan Tata Sosial Baru), Gramedia Pustaka Utama, Jakarta.

George Ritzer \& Douglas J. 2009. Goodman, Teori Sosiologi; dari teori sosiologi klasik sampai perkembangan teori sosial postmodern, Yogyakarta; Kreasi Wacana.

Fauzi, Noer. 2005. Gerakan-Gerakan Rakyat Dunia Ketiga, Resist Book. Yogyakarta.

Jenkins, Richard. 2013. Membaca Pikiran Pierre Bourdieu. Kreasi Wawana. Perum Sidorejo Bumi Indah (SBI). Bantul.

King Vitor T. 2013. The Best of Borneo Trave. New York: Oxford University Pres, 1996 (Penerjemah: Ratih Widyaningrum). Komunitas Bambu. Juli

Lawang, Robert M.Z. 2005 Kapital Sosial dalam Perspektif Sosiologik (Suatu Pengantar), FISIP UI Press. Jakarta.

Richard Harker, Cheelen Mahar, Chris Wilkes. 2004. (Habitus $\times$ Modal $)+$ Ranah $=$ Praktik, Pengantar Komprehensif kepada Pemikiran PierreBourdieu, terjemahan Pipit Maizier. Yogyakarta: Jalasutra.

Riwut, Tjilik. 197. Kalimantan Membangun. PT. Tirta Wacana, Yogyakarta.

Tsing, Anna L. 1998. Di bawah bayang-bayang Ratu Intan: Proses Marjinalisasi pada Masyarakat Terasing, penerjemah: Achmad Fedyani Saifuddin. Yayasan Obor Indonesia, Jakarta.

Turner, Jonathan H. 1998. The Structure of Sociological Theory. Belmont: Wadsworth Publishing Company.

Ukur, Fridolin. 197I. Tentang Jawab Suku Dayak, BPK Gunung Mulia. Jakarta.

Woolcock, Michael and Narayan, Deepa. 1999. Social Capital: Implications for Development Theory, Research and Policy. Final version submitted to the World Bank Research Observe, Vol. I5 (2). 